Pobrane z czasopisma Annales H - Oeconomia http://oeconomia.annales.umcs.pl Data: 26/04/2023 12:57:17

DOI:10.17951/h.2018.52.1.97

\begin{tabular}{lcl}
\hline & A N N A L E S \\
UNIVERSITATIS MARIAE CURIE-SKŁODOWSKA \\
LUBLIN - POLONIA \\
SOL. LII, 1 \\
SECTIO H
\end{tabular}

Warsaw School of Life Sciences. Faculty of Economic Sciences

SYLWESTER KOZAK

sylwester_kozak@sggw.pl

\title{
Low Interest Rates and Changes in the Banking Income Structure in EU Countries
}

Niskie stopy procentowe a zmiana struktury dochodów banków w krajach UE

Keywords: interest rates; financial markets; banks

Slowa kluczowe: stopy procentowe; rynki finansowe; banki

JEL Code: E430; G180; G210

\section{Introduction}

Loosening monetary policy by central banks in highly developed countries leads to lowering interest rates to levels close to zero. In several countries including Denmark, Japan, Switzerland, Sweden or the Euro Area, central banks imposed negative interest rates on some of their monetary policy instruments. The aim of such policy is to stop deflation and boost economic growth. However, ultra-low interest rates contribute to reduction in the net interest margin and lowering of the net interest income in banks. This situation exerts pressure on the banks to search for profits on, sometimes nontraditional, operations generating non-interest income. The process impacts the structure and stability of bank income.

The aim of this study is to investigate changes in the structure of banking income in the banking sectors of the EU member states in the years of 2008-2016, i.e. during the period of low and ultra-low interest rates. The data used in the research 
come from the Statistical Data Warehouse of the European Central Bank. The main hypothesis of the research states that the long-term maintenance of low interest rates contributes to lowering net interest margins and increasing the share of non-interest income in the banking income.

The rest of the article has the following structure: the second section presents conclusions from the literature review, and the third one presents the changes in the structure of the banking income that took place during the analyzed period. The final section summarizes the analysis.

\section{Non-interest income of banks - literature review}

The diversification of bank income and its impact on the banks' financial situation was a subject of analysis in the 1980s and 1990s, and its conclusions were mixed. Initially, the common way of diversifying bank income was to grant loans to entities operating in different economic sectors. Diamond [1996], examining the US banks operating between 1970 and 1985, states that the sectoral diversification of the loan portfolio positively influences bank performance. However, such relationship occurs under condition that the bank maintains ability to effectively monitor borrowers. Similar conclusions are reached by Archaya, Hasan and Saunders [2006] after examining the Italian banks operating in 1993-1999. They also find that sectoral and geographical diversification of the lending portfolio impacts bank credit risk in mixed ways. Strong sectoral diversification and granting loans to companies originating from new and highly competitive economic sectors undermine bank's ability to monitor borrowers and raise credit risk in the lending portfolio. Particularly, such relationship is noticed in the group of banks characterized by high credit risk. Risk mitigation in the portfolio of loans through geographic diversification is only efficient for banks with low credit risk.

Winton [1999] states that sectoral diversification of the lending portfolio in varied ways impacts the performance of US banks in the 1990s. Banks are most profitable when they moderately lend to companies operating in downward economic sectors. Diversification brings little benefits to banks whose lending portfolios are dominated by loans to businesses originating from the downward economic sectors. When banks limit the range of companies only to downstream sectors, the credit risk significantly increases and frequently leads to the banks' collapse. Conversely, Jensen [1986] and Berger and Ofek [1996] provide evidence against diversification. They argue that banks focusing on crediting entities from a narrow range of economic sectors achieve greater profits due to enhancing specialization, improving managerial skills and achieving economies of scale in their operations.

The introduction of banking directives in 1989 and 1992 in the European Union and the Financial Services Modernization Act of 1999 in the USA allowed banks to expand their business into other non-interest financial services. As a result, banks 
changed the way they diversify their earnings. This strategy was carried out mainly by large banks. Some of these non-interest bearing activities considerably deviated from the classical banking operations. However, implementation of such policy brought different results. Demirguc-Kunt and Huizinga [2010] analyze banks' activities during 1995-2007 and state that banks, with lower interest rate income, tend to increase their diversification and performance by offering non-interest income services, inter alia trading securities and loan securitization. However, in the long term perspective, such diversification unfavorably affects banks' profitability and raises credit risk in their lending portfolio. In many cases, it also causes the collapse of banks. A similar relationship exists in the area of funding of the banking operations. Expanding the scope of funding to money market instruments generates additional risk, mainly liquidity risk.

DeYoung and Rice [2004], while studying the income structure of the US banks in 1989-2001, find that the share of non-interest income in the total bank income gradually increased to $40 \%$. The non-interest income was rather complementary to the interest income than its replacement. Its value increased with the increase in the scale of banks' basic depository and lending activities. On this basis, they claim that interest income which still remains the main source of a bank income and that non-interest income should not be regarded either as a tool for the income diversifying or an alternative to interest income. They also note that more profitable banks slowly increase the share of non-interest income in their total income as opposed to less profitable banks. This relationship indicates that increasing non-interest income in line with the pace of total bank development may increase the level of bank's security and stability.

Similar conclusions are presented by Stiroh and Rumble [2006] on the basis of the study on financial holdings operating in the USA between 1997 and 2004. They find that benefits that holdings gain on introduction of new non-interest bearing operations are weakened by the increased risk and volatility of their total income. Additionally, they find that holdings that maintain a high share of non-interest income in the total income do not necessarily foster high rates of return on equity (ROE). Their investment portfolio is exposed to significantly higher risk compared to others.

Leaven and Levine [2006] examine the impact of income diversification on market valuation of financial institutions in the 1990s. They state that market value of financial conglomerate is lower than the sum of values of composing its separate entities. This means that benefits of the economy of scope are lower than costs associated with management of conglomerates combining entities with diversified business profiles and corporate cultures.

Lower income and higher cost in banks with greater geographical and product diversification are confirmed by Berger, Hasan and Zhou [2010] based on the research on Chinese banks operating during 1996-2006. After comparing two business models, i.e. providing narrow and wide ranges of deposit and loan products, they find that bank generates higher profits when provides a more specialized product offer to customers located in a geographically limited areas. 
Whereas, Williams [2016] argues that among Australian banks operating during 2002-2014 reduced risk is found in entities with lower share of non-interest rate income in total bank income and specializing in a narrower range of products. The recent study of Bikker and Vervliet [2017] on bank income diversification, indicates that US banks operating between 2001 and 2016 do not significantly increase the share of non-interest income in the total bank income despite long-term operation in a low interest rate environment and narrow net interest margins.

On the other hand, Alessandri and Nelson [2014] note that in the US banks with assets exceeding \$10MN during 2003-2010, an increase in non-interest income contributes to lowering credit risk. This rule particularly applies to banks where the income from custody services has been important. They argue that fiduciary services force bankers to exercise more cautious credit policies as these services are considered to be the most effective in raising the market value of a bank.

\section{Changes in the structure of income of European banks in 2008-2016}

Beginning in 2008, the European Central Bank and central banks of non-euro area Member States have systematically lowered their official interest rates (Fig. 1). One of the main goals of this policy was to reduce the cost of raising funds by businesses and households and stimulate economic development.

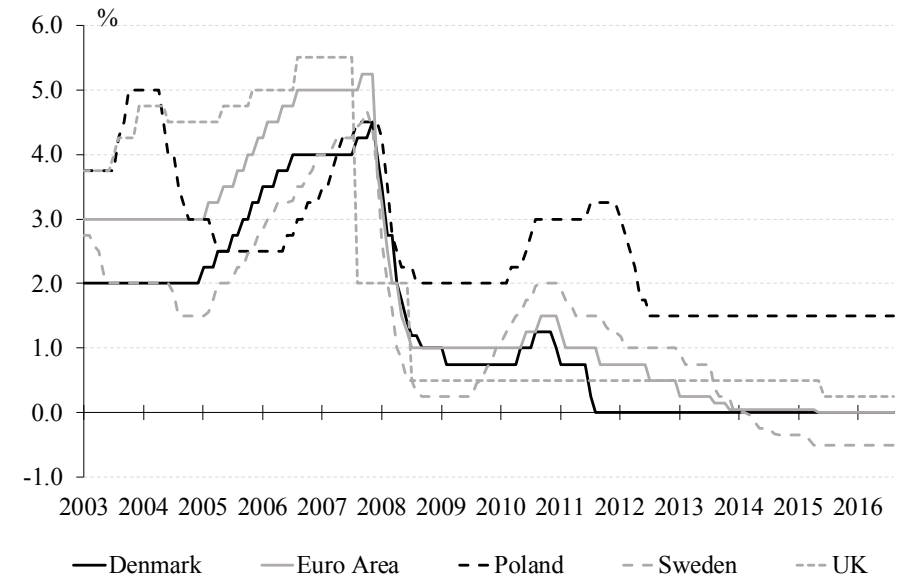

Fig. 1. Base rates of the central bank in selected European Union countries in 2003-2016 Source: web sites of central banks.

Central banks in the EU countries have started the process of lowering interest rates to near zero or even negative levels in 2011 and 2012. These decisions were a response to the ongoing crisis in economies of these countries and the growing 
negative effects of the public finance crisis experienced by most of the Western European countries. The long-term persistence of ultra-low interest rates has had a noticeable effect on the way the banks operate. Depending on their size and activity profile, banks adapted in different ways to the extraordinarily relaxed monetary policy. In the initial period, banks evenly reduced interest rates on loans and on deposits and maintained a similar net interest margin (Fig. 2). In many cases, much stronger reduction in interest rates on deposits compared to loans and an increase in the size of new loans has led to an improvement in the net interest income.

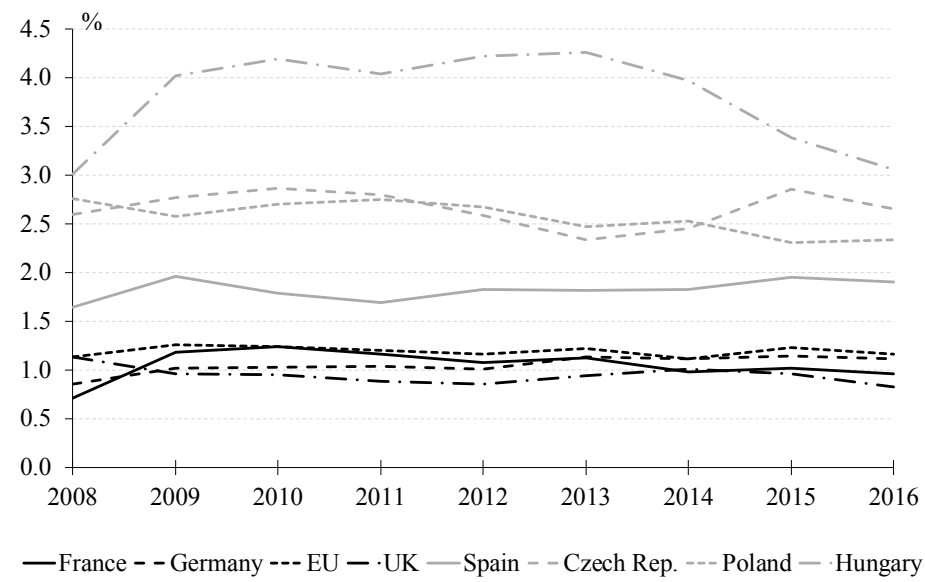

Fig. 2. Net interest income in relation to the assets in selected EU countries in 2008-2016

Source: own calculation based on the data of the ECB (Consolidated Banking Data).

In countries where the maturities of liabilities are considerably shorter than of loans, the drop in interest rate causes that aggregate interest rate on deposits falls earlier than on loans, which increases the net interest margin and the total interest income $^{1}$. In other countries, the banks aggressively lowered interest rate on deposits than on loans due to the increasing demand for deposits among households, as well as the transfer of funds from term deposits to current accounts ${ }^{2}$. The increase in demand for bank deposits resulted, among others, from the risk aversion of households experienced since the financial crisis. Households invest their savings in less profitable but safer bank deposits. An important advantage of bank deposits, compared to

1 National Bank of Belgium [2017, p. 25] informs about a significant increase of interest income achieved by banks despite falling interest rates in 2014 and 2015.

2 For instance, Banco de España in Financial Stability Report [May 2014, p. 33; November 2014, p. 34] informs about the increase in a spread between interest rate on assets and on liabilities and an interest income in 2012 and 2014. Additionally National Bank of Belgium [2016, p. 60] informs, that in 2015 interest rate on deposits fell by 35 bps, meanwhile on mortgages by 14 bps and on other loans by 24 bps. 
investment funds or shares of listed companies, comes from the administrative guarantee of deposits, which is set in the EU countries at the level of 100 thousand euro.

Smaller retail banks, which generate majority of income from interest rate operations, have undergone the pressure of narrowing their interest margins and interest income. They initially adjusted the interest rates on loans and on deposits to the monetary policy of the central bank. However, in the long term, the space for lowering interest rates on deposits has narrowed as it approached zero ${ }^{3}$. Not wanting to lose individual customers and small businesses, they were forced to reduce interest income. On the other hand, larger banks, which had easier access to finance in the money market and interbank lending market, were able to raise funds with a negative interest cost.

In many cases, the use of negative interest rate in financing did not offset losses of banks incurred due to a significant reduction in interest rates on loans. Another reason for the decline in interest income has been the reduction in business demand for bank loans, which became a source of increased competition among banks in providing lending services to large enterprises. Among others in Denmark, this problem became so significant that the Danish Financial Supervisory Authority carried out a special survey in 2015 and recommended monitoring procedures for granting loans to large enterprises to avoid excessive mitigation of lending standards and conditions [more: Danmarks Nationalbank, $1^{\text {st }}$ Half 2015, p. 10]. In the Netherlands, the increase in the sales of real estate boosted competition among banks in the mortgages market. However, the decrease in interest rates was limited due to the European Commission's ban on competition between banks receiving public aid [more: De Nederlandsche Bank, 2016, p. 22].

One of the forms of supplementing bank income, reduced by lower interest income, was the increase in non-interest income. Its size and share in total bank income have systematically increased in the EU banking sector, although the process varied across EU countries (Fig. 3). The increase in the importance of non-interest income in the EU banking system is evidenced by the fact that during 2008-2016 its growth rate significantly exceeded the growth rate of interest income. As a result, its relationship to interest income increased from $56 \%$ to $80 \%$. It is characteristic for France and the United Kingdom that non-interest income was higher or comparable with the interest income. In these countries, financial markets play an important role in the financial system. According to the European Central Bank, at the end of 2016 , the market capitalization in these countries amounted to $92 \%$ and $122 \%$ of GDP, respectively. 


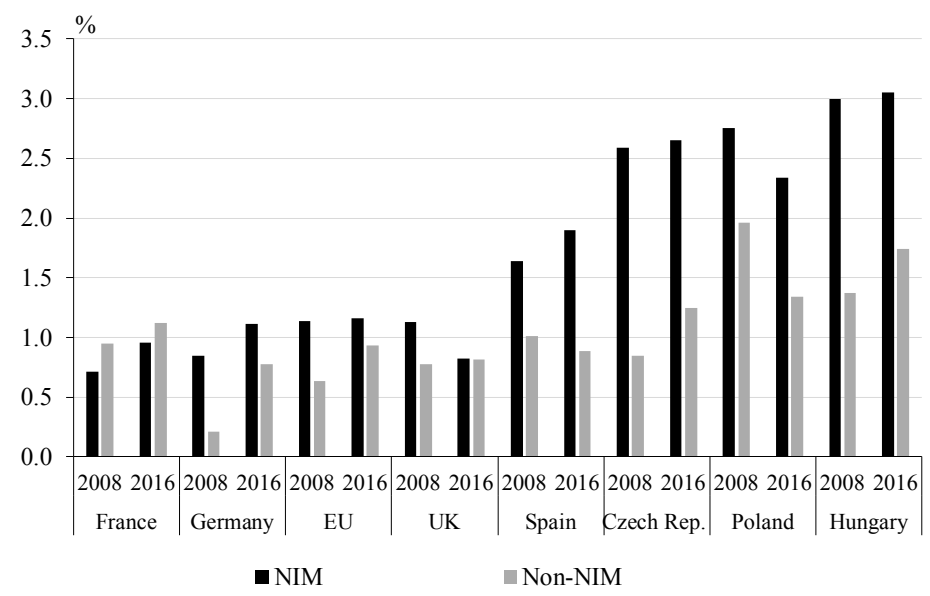

Note: NIM - net interest income to total assets, Non-NIM - net non-interest income to total assets

Fig. 3. Net interest and net non-interest incomes in relation to the assets in selected EU countries in 2008 and 2016

Source: own calculation based on the data of the ECB (Consolidated Banking Data).

The diversification of the banking business results is realized using two main strategies, i.e. by increasing the non-interest income of a complementary and substitutive nature in relation to interest income $e^{4}$. The first group includes commissions and fees related to lending, deposit and payment activities. In turn, the second group consists of fiduciary fees and commissions, income from trading in securities, issuing derivatives or selling third party investment instruments. In smaller banks and retail banks, non-interest income can be mainly included in the first category. Larger banks and banks with a universal profile have the ability to increase non-interest income from both categories. This means that they have more freedom in obtaining the results by using additional income, often with the implementation of non-traditional banking services.

The supervisory institutions of some EU countries note that the increase in the value and the share of non-interest income in total bank income is related to credit and deposit activities. For instance, the National Bank of Denmark points out that the increase in the value of newly granted and restructured housing loans significantly contributed to the increase in commissions and fees charged by banks for their subsequent administration [more: Danmarks Nationalbank, $2^{\text {nd }}$ Half 2015, p. 23]. The noticeable correlation of the value of fees and commissions with total banking operations causes that during the period of 2008-2016 in the EU, this income related to the bank assets was on average stable and amounted to about $0.6 \%$ (Fig. 4).

\footnotetext{
4 Such classification was used, inter alia, by DeYoung and Rice [2004].
} 
Pobrane z czasopisma Annales H - Oeconomia http://oeconomia.annales.umcs.pl Data: 26/04/2023 12:57:17

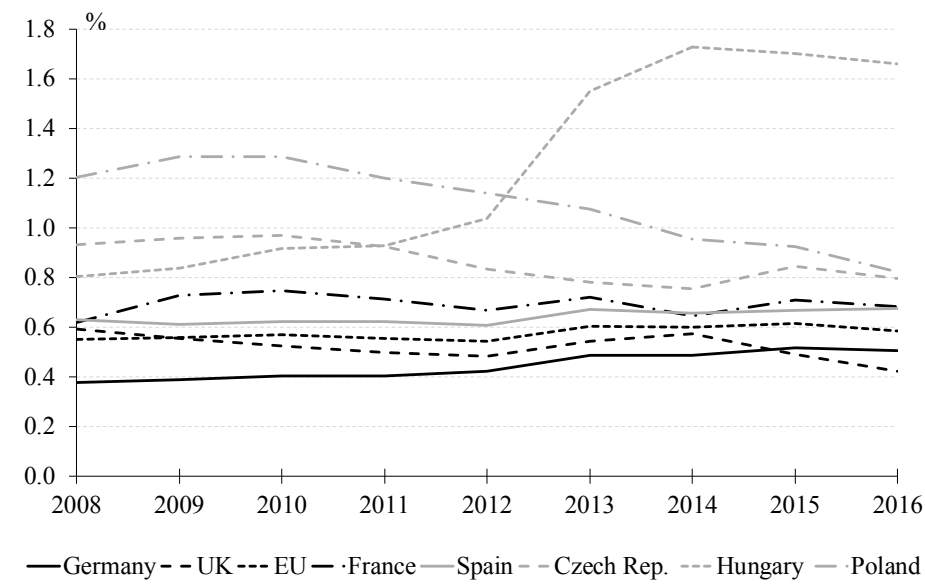

Fig. 4. Net fees and commissions in relation to the assets in selected EU countries in 2008-2016 Source: own calculation based on the data of the ECB (Consolidated Banking Data).

The non-interest income of supplementary nature is less stable. In contrast, income from commercial activity is significant (Fig. 5). Its value depends on the current market situation, which causes its considerable variability. For instance, in the Belgian banking sector, the value of trading income increased from negative $€(-2.7) \mathrm{BN}$ in 2009 to $€ 0.8 \mathrm{BN}$ in 2013 , then it fell to $€(-0.1) \mathrm{BN}$ in 2014 , and again increased to $€ 1.5 \mathrm{BN}$ in 2016 [more: National Bank of Belgium, 2016, p. 50]. Similar volatility was recorded in the Spanish banking sector, where the ratio of income on financial operations to the total assets changed from $0.1 \%$ in 2012 to $0.4 \%$ in 2013 and $0.2 \%$ in 2016 . These changes were significantly affected by the volatility of the euro against the US dollar and the Mexican peso [more: Banco de España, 2014, p. 33; Banco de España, 2017, p. 64].

a)

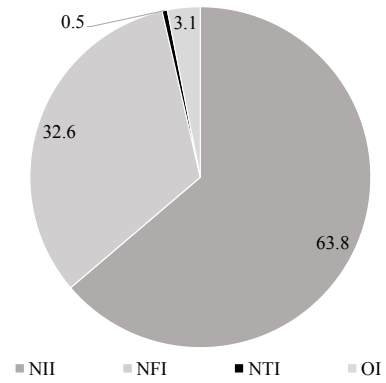

b)

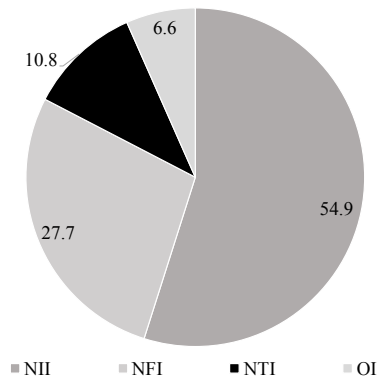

Note: NII - net interest income, NFI - net fees and commissions, NTI - net income from trading activity, OI - other income

Fig. 5. Structure of the income from banking activity in the EU in 2008 (panel a) and 2016 (panel b)

Source: own calculation based on the data of the ECB (Consolidated Banking Data). 
Comparing the changes in the share of the non-interest income in the total bank income in the EU countries during 2008-2016, it can be noted that income from the trading activity characterizes with the highest volatility. The value of the volatility index for this category of bank income is the highest, excluding the small value of other income (Table 1). This means that bank trading activities are a risk factor rather than a stabilizer of bank profitability.

Table 1. Structure of the income from banking activity in the EU countries in 2008-2016 (\%)

\begin{tabular}{|l|c|c|c|c|}
\hline \multicolumn{1}{|c|}{ Income } & Average & Median & Standard deviation & Volatility index \\
\hline Net interest income & 65.3 & 64.6 & 15.7 & 0.24 \\
\hline Net fees and commissions & 24.5 & 23.8 & 7.9 & 0.32 \\
\hline Net income from trading activity & 6.9 & 7.6 & 10.1 & 1.45 \\
\hline Other income & 3.8 & 4.6 & 6.8 & 1.77 \\
\hline
\end{tabular}

Source: own calculation based on the data of the ECB (Consolidated Banking Data).

\section{Conclusions}

The loose monetary policy conducted by central banks after the global financial crisis has led to establishment of zero or even negative interest rates. Long-term low interest rates have contributed to lowering net interest margin and interest income, especially in smaller and retail banks.

In order to maintain a stable level of total income, banks increase their share of non-interest income. Large share of fees and commissions is related to the deposit and lending activities, hence, their value is increasing as a result of the expansion of bank lending.

Larger banks are more engaged in their own trading activities. The value of income generated by these operations is increasing, however, it is characterized by significantly high volatility. As a result, trading activities are rather a source of risk and they should not be treated as a factor in stabilizing bank income during periods of economic downturn and slowdown of lending activities.

\section{Bibliography}

Alessandri P., Nelson B., Simple banking: Profitability and the yield curve, "Journal of Money, Credit and Banking" 2014, Vol. 47(1), DOI: https://doi.org/10.2139/ssrn.2413438.

Archaya V., Hasan I., Saunders A., Should banks be diversified? Evidence from individual bank loan portfolios, "Journal of Business" 2006, Vol. 79.

Banca D'Italia, Financial Stability Report, No. 2, 2016.

Banco de España, Financial Stability Report, May 2014.

Banco de España, Financial Stability Report, November 2014.

Banco de España, Financial Stability Report, November 2016.

Banco de España, Financial Stability Report, November 2017. 
Berger A., Hasan I., Zhou M., The effects of focus versus diversification on bank performance: Evidence from Chinese banks, "Journal of Banking and Finance" 2010, Vol. 34,

DOI: https://doi.org/10.1016/j.jbankfin.2010.01.010.

Berger P.G., Ofek E., Bustup Takeovers of Value-Destroying Diversified Firms, "Journal of Finance" 1996, Vol. 51(4), DOI: https://doi.org/10.1111/j.1540-6261.1996.tb04066.x.

Bikker J., Vervliet T., Bank profitability and risk-taking under low interest rates, "DNB Working Paper" 2017, No. 560.

Council Directive 92/30/EEC of 6 April 1992 on the supervision of credit institutions on a consolidated basis (OJ L 110, 28.04.1992, pp. 52-58).

Danmarks Nationalbank, Financial Stability, $1^{\text {st }}$ half $2015,2^{\text {nd }}$ half 2015.

Danmarks Nationalbank, Financial Stability, $2^{\text {nd }}$ half 2015.

De Nederlandsche Bank, Financial Stability Report, Autumn 2016.

Demirguc-Kunt A., Huizinga H., Bank activity and funding strategies: The impact on risk and returns, "Journal of Financial Economics" 2010, Vol. 98(3), DOI: https://doi.org/10.1016/j.jfineco.2010.06.004.

Deutsche Bundesbank, Financial Stability Review, November 2015.

DeYoung R., Rice T., Non-interest income and financial performance at U.S. commercial banks, "The Financial Review" 2004, Vol. 39, DOI: https://doi.org/10.1111/j.0732-8516.2004.00069.x.

Diamond D., Financial Intermediation as Delegated Monitoring: A Simple Example, "Federal Reserve Bank of Richmond Economic Quarterly" 1996, Vol. 82/3.

Jensen M., Agency Costs of Free Cash Flow, Corporate Finance, and Takeovers, "The American Economic Review" 1986, Vol. 76(2).

Laeven L., Levine R., Is there a diversification discount in financial conglomerates?, "Journal of Financial Economics” 2007, Vol. 85, DOI: https://doi.org/10.1016/j.jfineco.2005.06.001.

National Bank of Belgium, Financial Stability Report, June 2016.

National Bank of Belgium, Financial Stability Report, June 2017.

National Bank of Poland, Financial Stability Report, January 2015.

Second Council Directive 89/646/EEC of 15 December 1989 on the coordination of laws, regulations and administrative provisions relating to the taking up and pursuit of the business of credit institutions and amending Directive 77/780/EEC (OJ L 386, 30.12.1989, p. 1).

Stiroh K., Rumble A., The dark side of diversification: The case of US financial holding companies, "Journal of Banking and Finance" 2006, Vol. 30, DOI: https://doi.org/10.1016/j.jbankfin.2005.04.030.

The Financial Services Modernization Act of 1999 (Pub. L. 106-102, 113 Stat. 1338).

Williams B., The impact of non-interest income on bank risk in Australia, "Journal of Banking and Finance" 2016, Vol. 73, DOI: https://doi.org/10.1016/j.jbankfin.2016.07.019.

Winton A., Don't Put All Your Eggs in One Basket? Diversification and Specialization in Lending, "Working Paper. University of Minnesota" 1999.

\section{Niskie stopy procentowe a zmiana struktury dochodów banków w krajach UE}

Luzowanie polityki monetarnej banków centralnych, prowadzone od momentu wybuchu globalnego kryzysu finansowego, doprowadziło do ustanowienia zerowych lub nawet ujemnych stóp procentowych. Analiza danych EBC i banków centralnych państw członkowskich UE za lata 2008-2016 wskazuje, że długoterminowe utrzymywanie bardzo niskich stóp procentowych przyczynia się do obniżenia marży odsetkowej netto i przychodów odsetkowych, zwłaszcza w mniejszych bankach i bankach detalicznych. Banki systematycznie zwiększają udział w dochodach nieodsetkowych w strukturze dochodów z działalności bankowej. Największą kategorią takich dochodów są opłaty i prowizje, w znacznej mierze wynikające z realizacji operacji depozytowych i kredytowych. Drugim źródłem dochodów nieodsetkowych są operacje handlowe banków. Dochód ten charakteryzuje się jednak najwyższą niestabilnością, co sprawia, że jest źródłem ryzyka i nie może być traktowany jako stabilizator dochodów banków w okresach spowolnienia gospodarczego i ograniczenia akcji kredytowej. 
Pobrane z czasopisma Annales $\mathrm{H}$ - Oeconomia http://oeconomia.annales.umcs.pl Data: 26/04/2023 12:57:17

\section{Low Interest Rates and Changes in the Banking Income Structure in EU Countries}

The relaxed monetary policy of central banks conducted after the global financial crisis has led to the establishment of zero or even negative interest rates. Based on data from the ECB and central banks of the EU Member States for the years 2008-2016, it has been noted that the long-term maintenance of ultra-low interest rates contributes to a reduction in net interest margin and interest income, particularly in smaller banks and retail banks. Banks systematically increase the share of non-interest income in the structure of income from banking activity. The largest category of such income is fees and commissions, largely related to the performance of deposit and credit activities. The second sources of non-interest income are the bank trading activities. That income is characterized by the highest volatility, which makes it a source of risk and cannot be treated as a stabilizer of banks' income during times of economic downturn and slowing down in lending. 